\title{
The Impact of Tourism Marketing on the Attracted Tourists in the Shaqlawa
}

\author{
DASHTI HUSSAIN ALI \\ Business administration department, Shaqlawa technical college, ERBIL POLYTECHNIC UNIVERSITY, IRAQ, \\ E-mail: dashtihussin@epu.edu.iq
}

\begin{abstract}
This study concluded that tourism marketing is one of the main factors for the advancement of this sector. Its importance stems from the role it plays in transforming tourism into an arena for competition among all countries of the world, as each country tries to highlight its tourism components in order to acquire the largest possible share of the exporting markets for tourists, and that is by creating a positive image and implanting it in the minds of tourists, based on various marketing policies. This is what was confirmed by the findings, as we find that the tourism sector in Erbil, specifically in the Shaqlawa district, and despite the available tourism resources and attractions for tourists, is still far from the ranks of Arab and international tourism competitiveness, and this was evident through the late ranks it occupied In the index of global competitiveness for tourism and travel for the year 2021, in addition to comparing the reality of tourism in both Iran and Turkey, and the result was the absence of a tourism development plan that reflects the tourism potential in the country, and actually adopts the application of the rules and foundations of tourism marketing. Tourism development does not depend only on the availability of tourism resources and tourist attractions, but on how to use and exploit those resources in the tourism development process.
\end{abstract}

Key words: Tourism; Tourism marketing; Tourism development; Tourism competitiveness; Shaqlawa district.

\section{JEL Classification: J}




\title{
El Impacto del Marketing Turístico en la Atracción de Turistas en la Shaqlawa
}

\author{
DASHTI HUSSAIN ALI \\ Business administration department, Shaqlawa technical college, ERBIL POLYTECHNIC UNIVERSITY, IRAQ, \\ E-mail: dashtihussin@epu.edu.iq
}

\begin{abstract}
RESUMEN
Este estudio concluye que el marketing turístico es uno de los principales factores para el avance de este sector. Su importancia radica en el papel que desempeña en la transformación del turismo en un escenario de competencia entre todos los países del mundo, ya que cada país trata de destacar sus componentes turísticos para adquirir la mayor cuota posible de los mercados exportadores de turistas, y ello mediante la creación de una imagen positiva y su implantación en la mente de los turistas, basándose en diversas políticas de marketing. Esto es lo que confirmaron los resultados, ya que encontramos que el sector turístico de Erbil, concretamente en el distrito de Shaqlawa, y a pesar de los recursos turísticos disponibles y las atracciones para los turistas, todavía está lejos de los rangos de competitividad turística árabe e internacional, y esto se puso de manifiesto a través de los rangos tardíos que ocupó en el índice de competitividad global para el turismo y los viajes para el año 2021, además de comparar la realidad del turismo tanto en Irán como en Turquía, y el resultado fue la ausencia de un plan de desarrollo turístico que refleje el potencial turístico en el país, y que realmente adopte la aplicación de las normas y fundamentos del marketing turístico. El desarrollo del turismo no depende únicamente de la disponibilidad de recursos turísticos y de atracciones turísticas, sino de cómo utilizar y explotar esos recursos en el proceso de desarrollo turístico.
\end{abstract}

Palabras claves: Turismo; Marketing turístico; Desarrollo turístico; Competitividad turística; Distrito de Shaqlawa.

\section{Clasificación JEL: J}




\section{Introduction}

The world is witnessing important developments in the field of services that have become of great importance in the economies of the countries, where they are linked economic growth with the effectiveness and diversity of the services provided, as well as the developments in the marketing concept that led to improving services in different spaces. Highlight the role that the service sector plays in every context. The tourism sector is among the service sectors that have emerged in importance in recent times, as tourism is no longer today and its importance has increased as a mere entertainment activity confined to eating, drinking and picnicking. It has become an export industry in itself (Dabidianet al., 2013: Naidoo et al., 2010))

Other mechanisms, social, cultural, economic, and even environmental, and the role they play due to their close association with various countries upgrading the infrastructure (Rayan, 2018).

Tourism today occupies a privileged position that competes with the oil and industry sectors, in terms of its contribution to the gross national product. In many countries, as some countries depend on it almost completely, and with the development of the modern marketing concept, especially in developed countries, and countries that enjoy the same and the emergence of the concept of tourism marketing, and the growing interest means of transporting with the elements of tourist attraction, as this sector has become one of the sectors that are witnessing increasing growth as well Collecting and modernizing them provides ample areas for manpower recruitment and a tool for the advancement and development of civilizations, as well as his behaviors, in addition to the role it plays in improving the level of economic performance, and contributing to bringing in the currency hard, improving balance of payments (Kotler et al., 2003).

If tourism marketing has become a necessity necessitated by the competitive nature of the markets in which tourism enterprises operate, confrontation as the intense competition invited the tourism institutions to seriously think about how they could be challenges posed by that competition, and the dynamism of needs and desires for the tourism service helped the development of modern trends in tourism establishments, which contributed to strengthening the concept of marketing in the performance and presentation (Laws,2002, Elmagzoub et al 2020).

Tourist service, then the modern concept of marketing appeared, which is based on the consumer and takes the satisfaction of his needs and desires an essential axis around which all marketing efforts and activities revolve. Marketing activity was not limited to goods and services modern lightening. Stereotypes, and even extended to the tourism industry as it represents a source of income in the Iraq country is among the developing countries that enjoy a variety of tourism resources, including climatic, regional, and social cultures the archaeological landmarks and archaeological monuments it has left behind are world-famous, all of them having multiple traditions, in addition to the ancient civilizations that have passed this boosts the tourist stock in Shaqlawa district (Al-Houri, 2000).

The economic situation in Kurdistan region now makes it imperative to search for alternatives that enable the country to overcome the crisis and to achieve the dominant goals of promoting and developing tourism and making it another source of wealth after fuel and building an attractive tourist destination for tourists and investors (Meier, 1968 , saqib et al 2019).

The Shaqlawa district is considered one of the oldest and oldest tourist cities in northern Iraq, as it is rich in a huge amount of cultural, archaeological and natural resources.

From waterfalls, lakes, and ancient palaces, in addition to its history of struggle during the Kurdish liberation revolution, it has a cultural, civilizational and historical diversity (AL-Taee et al., 2017).

\subsection{The problematic research}

Through what we mentioned previously, we can raise the following problem:

What is the role of tourism marketing in promoting tourism services?

And fall under this problem the following sub-questions: 
1) What is meant by tourism and tourism marketing? What is meant by the promotion of tourism services?

2) How can tourism marketing contribute to improving tourism services?

3) What are the tourism potentials that the Shaqlawa district possesses, and what is the reality of tourism marketing in it?

4) What are the most important difficulties and obstacles that stand in the way of developing the tourism sector in Shaqlawa district?

\subsection{Research hypotheses}

To answer the aforementioned questions, the following hypotheses can be formulated:

1. The improvement of tourism services depends on the method of promotion used.

2. Tourism marketing in Shaqlawa district suffers from a number of problems, which leads to the lack of tourism activity. The role assigned to him in advancing local development.

Search limits

- Thematic framework: The study dealt with the role of tourism marketing in developing tourism for the Shaqlawa district, as applied to the visitors and visitors of the city.

- Spatial framework for research: The spatial framework for research is represented in hotels and tourist resorts in the city as a field of field study.

The time frame for the research: The researcher was selected for this time period between February 2021 until April 2021, considering the spring season in the city.

As it is considered the most appropriate period and the most recent as well, as it witnessed pioneers and tourists in the city and achieved remarkable records in the tourism field at the local level for Iraq based on the latest statistics, and also among the reasons for choosing the researcher for this period to live with this period with knowledge and follow-up by virtue of the nature of his work (memon et al 2017).

The steps taken by the researcher in preparing and distributing 200 form (expert questionnaire). The number of right return were 195 form and 5 ignore because not well filled.

\section{A. Selection of the research sample:}

The research sample was chosen from the residents of Shaqlawa hotels and its outskirts in an intentional manner, and it is one of the non-probability samples that the researcher chooses to obtain certain opinions or information that can only be obtained from that category.

The (Cronbach's Alpha) parameter was used to measure internal consistency as it contributes to measuring the internal consistency of the study statements in order to verify the validity of the performance.

The descriptive statistical method was used: which is considered the best method for describing the characteristics of the units of analysis between the arithmetic mean, the standard deviation, and arranging the units according to the degree of the arithmetic mean, and then working on comparing it with the hypothetical arithmetic mean resulting from the sum of 5 divided by the number 5 , and from Then it has the mean $(1+2+3+4+5$ degrees of the five-stage scale) which are the hypothetical arithmetic degrees, which is equivalent to (3) degrees.

Contents of the questionnaire: There were 5 open questions in the form related to submitting an evaluation and opinions on the topic of the research, and the questionnaire consisted of (15) questions consisting as following:

The first part: Personal data and it consists of two questions.

The first axis: It consists of (3) questions

The second axis: It consists of three parts, first part consists of (4) questions about treat people of Shaqlawa district with visitors, second parts consist of (10) questions about visitor's opinion how to 
development the marketing tourism in Shaqlawa district and the last part consists of (1) free questions.

- The questionnaire included the following axes:

$>\quad$ The questionnaire started by personality information such as (Qualification, Marital Status, gender and age).

$>\quad$ The first axis (tourism services).

$>\quad$ The second axis (deal with tourists).

$>\quad$ The field of achieving a good reputation at the level of the tourism sector in the Department of Tourism in Iraqi Kurdistan and its official bodies.

$>\quad$ The field of activities and functions that the Shaqlawa district and its affiliated bodies exercises in general.

$>\quad$ Activities and tasks related to tourism marketing carried out by the management of its affiliated bodies.

$>\quad$ The main roles of hotels and tourist resorts in the city

$>\quad$ The viewpoint of visitors in the context of tourism marketing

$>\quad$ The most important means used for the purpose of developing tourism marketing.

$>\quad$ As well as on the open-ended question axis.

$>\quad$ Bellow the list of questionnaire with symbol of questions

\begin{tabular}{|c|c|c|c|c|c|c|}
\hline \multirow[b]{2}{*}{ Symbol } & \multirow[b]{2}{*}{ Question } & \multicolumn{5}{|l|}{ Answers } \\
\hline & & $\begin{array}{l}\text { Strongly } \\
\text { agree }\end{array}$ & Agree & $\begin{array}{l}\text { To } \\
\text { some } \\
\text { extent }\end{array}$ & $\begin{array}{l}\text { Not } \\
\text { agree }\end{array}$ & $\begin{array}{l}\text { Strongly } \\
\text { disagree }\end{array}$ \\
\hline $\mathrm{X} 1$ & $\begin{array}{l}\text { Is there an improvement in the services if you visited the } \\
\text { city before? }\end{array}$ & & & & & \\
\hline $\mathrm{x} 2$ & $\begin{array}{l}\text { Do you deal with the people of the city at the level of } \\
\text { ambition? }\end{array}$ & & & & & \\
\hline X3 & $\begin{array}{l}\text { Do you feel that the shopkeepers are taking advantage of } \\
\text { you as an expatriate? }\end{array}$ & & & & & \\
\hline $\mathrm{X} 4$ & $\begin{array}{l}\text { Do you find that the owners of internal transportation have } \\
\text { their prices at an adequate level }\end{array}$ & & & & & \\
\hline X5 & $\begin{array}{l}\text { Do you find they deal with you with a national, class and } \\
\text { sectarian difference? }\end{array}$ & & & & & \\
\hline $\mathrm{x} 6$ & $\begin{array}{l}\text { Do you think that the level of tourism in Shaqlawa is at a } \\
\text { competitive level with other provinces of Iraq? }\end{array}$ & & & & & \\
\hline $\mathrm{X7}$ & $\begin{array}{l}\text { How to find hotel services in the city of Shaqlawa with the } \\
\text { level of ambition }\end{array}$ & & & & & \\
\hline $\mathrm{x} 8$ & $\begin{array}{l}\text { Do you think that there should be a role for the media to } \\
\text { improve the level of tourism in Shaqlawa? }\end{array}$ & & & & & \\
\hline X9 & $\begin{array}{l}\text { Do you agree that there is a role for tourist offices in your } \\
\text { city to stimulate tourism in Shaqlawa? }\end{array}$ & & & & & \\
\hline $\mathrm{X} 10$ & $\begin{array}{l}\text { Do you support the existence of free publications and } \\
\text { brochures distributed for free as a tourist guide for the city } \\
\text { of Shaqlawa? }\end{array}$ & & & & & \\
\hline $\mathrm{X} 11$ & Do you support the necessity of a tourist guide for the city? & & & & & \\
\hline $\mathrm{X} 12$ & $\begin{array}{l}\text { Do you think that the services in the tourist areas of } \\
\text { Shaqlawa in terms of cleanliness and service are of the } \\
\text { required level? }\end{array}$ & & & & & \\
\hline $\mathrm{X} 13$ & $\begin{array}{l}\text { Do you think that the district office should contribute to the } \\
\text { establishment of free entertainment parties for tourists? }\end{array}$ & & & & & \\
\hline $\mathrm{X} 14$ & $\begin{array}{l}\text { Would you like to visit the city of Shaqlawa, and visit it } \\
\text { again? }\end{array}$ & & & & & \\
\hline X15 & $\begin{array}{l}\text { The axis on how the people of Shaqlawa dealt with the } \\
\text { tourists }\end{array}$ & & & & & \\
\hline
\end{tabular}




\section{B. Measuring instrument calendar:}

The following was taken into account in building the questionnaire:

The wording should be clear and the words legible be easy and sound of the language

The logical sequence of questions not to duplicate goals in one statement.

To contain a number of axes

Form arbitration: The researcher presented the form in its initial form to a number of faculty members and some experts and specialists for arbitration.

\section{Test the validity and reliability of the form}

Truthfulness means the ability of performance to implement the objectives for which it was designed, and the researcher relied on the extent of the validity of the form on the apparent validity, and what is meant by the apparent validity is the extent of the relevance of the form's decision to the objectives for which it was designed, which indicates the general form of the form and the extent of clarity and relevance of the language for the sample, the clarity of the instructions and the correctness of the arrangement of the basic steps, the apparent validity of the form was verified to present its report to the arbitrators, as we have explained, in order to provide their opinions on the form and confirm its validity distributable.

\section{Validate scale:}

The validity test was performed with the expressions of the questionnaire by computing the square root of the A. Cronbach factor as follows table:

\begin{tabular}{lll}
\hline Cronbach's Alpha & & \\
\hline Var. & Cronbach's Alpha & $\mathrm{N}$ of Items \\
\hline The first axis (tourism services). & 0.782 & 10 \\
The second axis (deal with tourists) & 0.733 & 4 \\
\hline Total & 0.724 & 14 \\
\hline
\end{tabular}

Through the above table, which represents the estimation of the reliability coefficient, where the stability of the scale was tested for the questionnaire questions for the two variables with its paragraphs, as well as the reliability coefficient was calculated for the questionnaire questions as a whole and it was found that the value of the reliability coefficient was $72 \%$ and this indicates the stability of the questionnaire questions and that the values of the parameter used for the variables containing the paragraphs were acceptable.

The respondents' answers were coded in order to facilitate their entry into the computer for statistical analysis according to the following standard weights:

\begin{tabular}{lll}
\hline Strongly agree & Weigh & $>\mathbf{5}$ \\
\hline Agree & Weigh & $>4$ \\
Neutral & Weigh & $>3$ \\
Do not agree & Weigh & $>2$ \\
Never agree & Weigh & $>1$ \\
\hline
\end{tabular}

Hypothetical mean $=$ sum of weights $1+2+3+4+5 / 5=3$

And its purpose is to calculate the hypothetical mean is to compare it with the actual arithmetic mean of the statement, as if the actual mean is reduced

To express the hypothetical mean, this indicates that the respondents do not agree with the statement, but if the arithmetic mean is increased this indicates the respondents 'agreement to the statement. 
To test the frequency of the respondents' answers, and whether they are in the positive or negative direction, the researcher used a square test (Chi- Square orX2) for the quality of congruence, the next hypothesis test, to what extent the frequency obtained from the answers respondents are distributed in equal (regular) proportions of expressions (strongly agree, agree, neutral, disagree, and absolutely disagree or never agree).

\section{E. Statistical analysis and proof of results:}

To analyze the data on the expert questionnaire, the researcher used the statistical analysis program (SPSS), and the researcher reviewed the presentation of each statement in a table showing the number of repetitions and the percentage of each response, and the researcher used the figures the explanatory notes to clarify the percentages, and then commented on the result of each statement of the questionnaire, and to know the direction of the views of the research sample regarding all the expressions of the questionnaire, then the calculation of the arithmetic mean and the standard deviation and chi-square test, measuring degrees of freedom and probability value.

Presentation and interpretation of data.

Knowing the extent to which the sample respondents' answers to the expert questionnaire questions are correct, scientifically based and applicable. In order to perform statistical analysis on it, it requires knowledge of some of the characteristics of the individuals of the research sample from specialists'. The following is a description of the characteristics (primary data) of the respondents of the research sample on whom the research was conducted:

Table: Clear the type and percentage of gender:

\begin{tabular}{lll}
\hline Type of gender & Replicate & Percentage \% \\
\hline Male & 121 & 62.05 \\
Female & 74 & 37.95 \\
Total & 195 & $100 \%$ \\
\hline
\end{tabular}

The table prepared by researcher depended on data Questionnaire form

Figure No. 1. Shows the type of gender

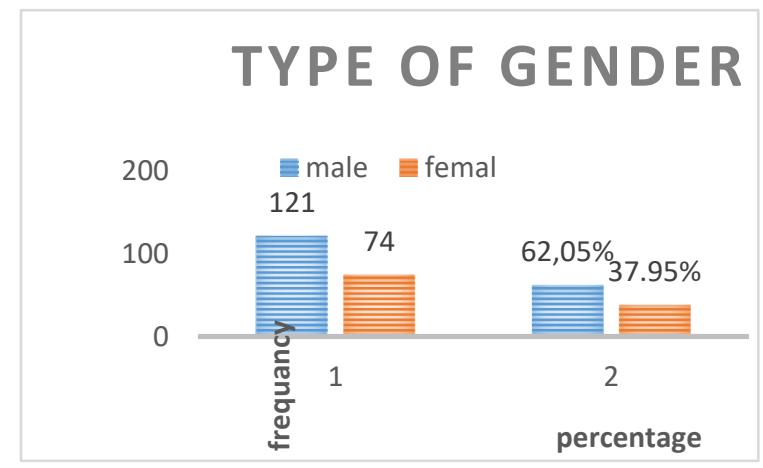

It is evident from the table and the above figure that the number of males in the surveyed sample is greater than the number of females with a rate of 62.05 for males, and the percentage of females is (37.95\%), and the researcher believes that this indicates that women also have an effective role in expressing an opinion, especially in tourism marketing in Shaqlawa district. 
Table: Age Group

\begin{tabular}{lll}
\hline Category Age & Frequency & Percentage \% \\
\hline Under 18 years old & 20 & 10.26 \\
\hline $\mathbf{1 8 - 3 5}$ years old & 45 & 23.08 \\
\hline $\mathbf{3 6 - 4 5}$ years old & 55 & 28.21 \\
$\mathbf{4 7 - 5 5}$ years old & 45 & 23.08 \\
\hline $\mathbf{5 6 - 6 5}$ and over years old & 30 & 15.38 \\
\hline Total & 195 & $100 \%$ \\
\hline
\end{tabular}

The table prepared by researcher depended on data Questionnaire form

Figure No. 2. Age Group

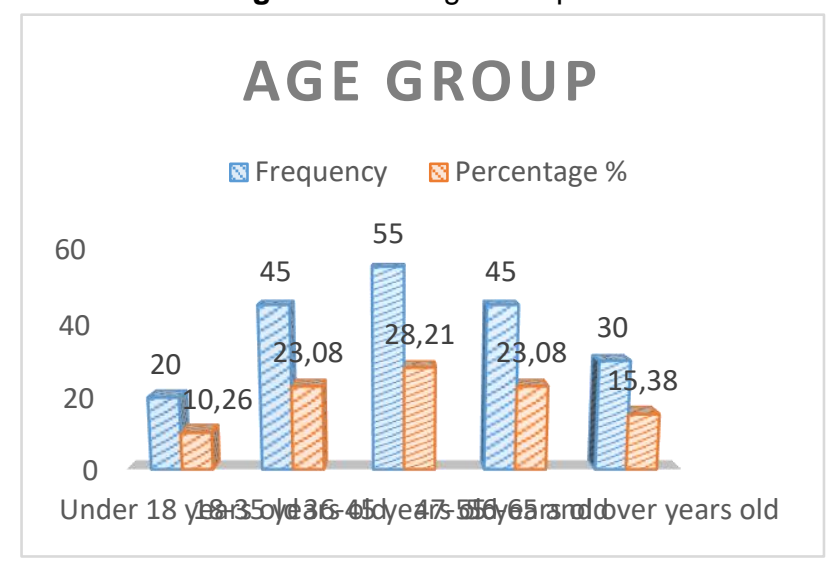

It is clear from the table and the above figure that the majority of the sample members are the first percentage of the age category $36-45(28.21 \%)$ and the second category age $18-35(23.08 \%)$ years and this indicates the dependence on the mature youth group at all levels - senior management, and this provides opportunities for ideas of renewable talent.

Table: Marital Status

\begin{tabular}{lcc}
\hline Marital Status & Frequency & Percentage \\
Married & 64 & 32.8 \\
Single & 125 & 64.1 \\
Widower & 5 & 2.5 \\
Divorced & 1 & 0.5 \\
Total & 195 & $100 \%$ \\
\hline
\end{tabular}

The table prepared by researcher depended on data Questionnaire form

Figure No. 3. Marital statement

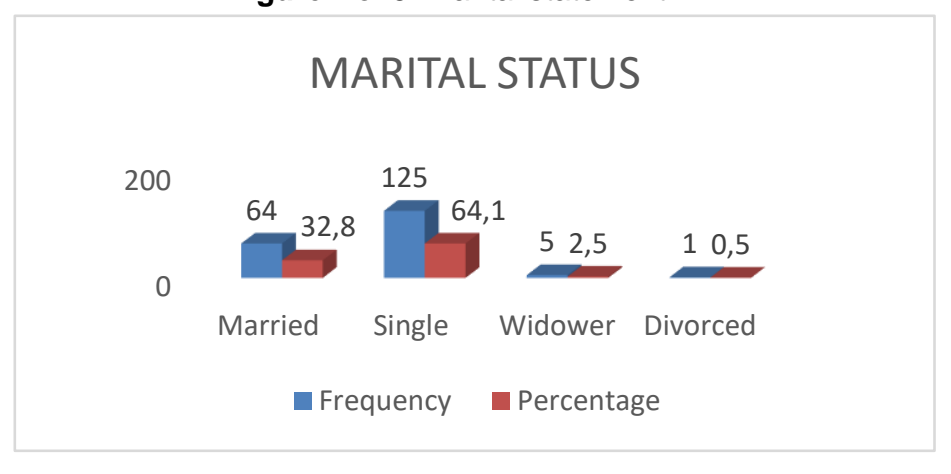


It is evident from the above table and figure that the majority of the sample are from unmarried people (single), as their frequency reached 125 out of 195 person, the highest rate of 64.1, and this indicates that in the spring season most of the leisure trips come in which young people come because they found Shaqlawa district as an outlet for their tourism on one side and on the other side inside the country at a lower cost, in addition to the economic and health situation that has become It is prohibited to travel to foreign and neighboring countries such as Turkey due to fear of the Corona epidemic. It also comes in second place, those married with 64 repeaters out of 195 , at a rate of $32.8 \%$, which is a good percentage for tourism marketing.

Table: Academic level

\begin{tabular}{lcc}
\hline Qualification & & \\
\hline & Frequency & Percent \\
\hline $\begin{array}{l}\text { Not good at reading } \\
\text { and writing }\end{array}$ & 27 & 13.8 \\
Elementary School & 21 & 10.8 \\
Middle school & 30 & 15.4 \\
High school & 68 & 34.9 \\
\hline University education & 49 & 25.1 \\
\hline Total & 195 & 100 \\
\hline
\end{tabular}

The table prepared by researcher depended on data Questionnaire form

Figure No. 4. Academic level

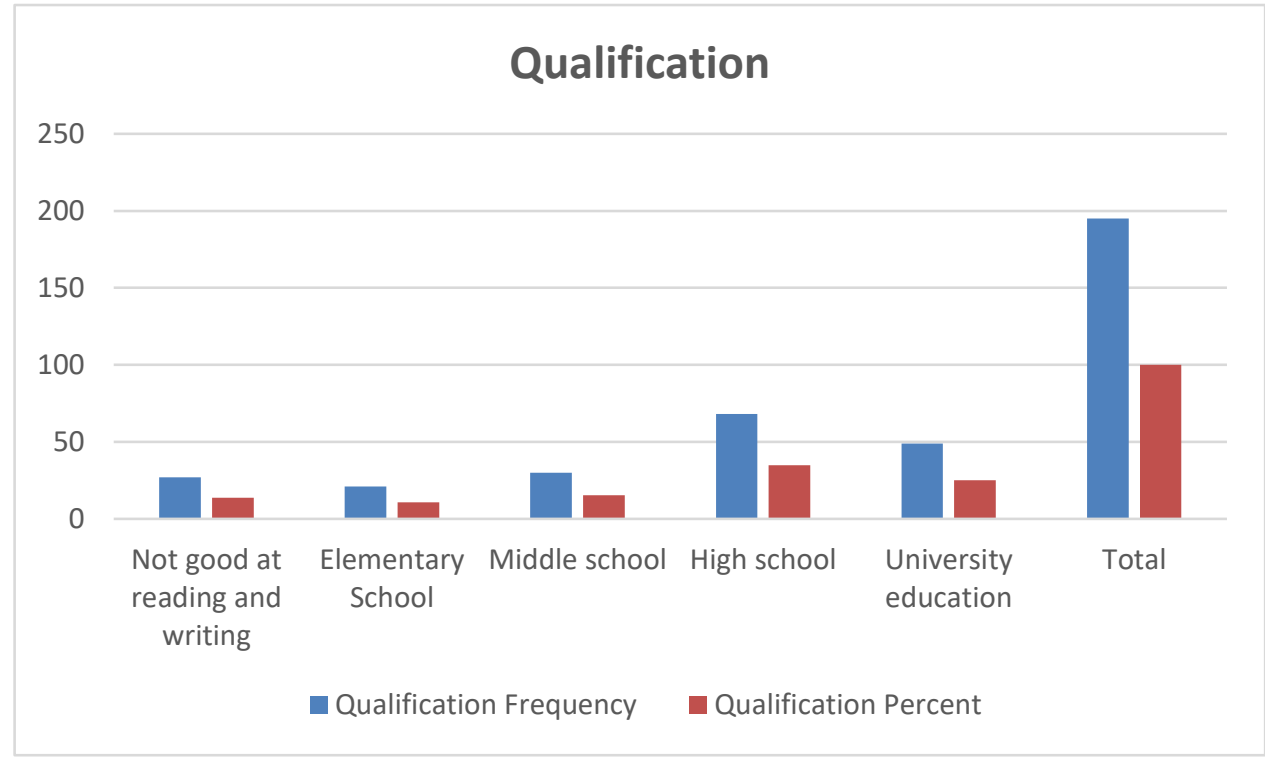

From the above table, represented secondary the higher percentage of s school graduated girls with a percentage of (60\%) from the population included in the study. This related to the accuracy of the answers concerning the educational level in this population. This also reflects the tremendous responsibility feel during answering the questionnaire points

The first axis includes questions related to the situation of tourism in Shaqlawa district.

The table prepared by researcher depended on data Questionnaire form

From this table it is obvious that highest percentage to the category (agree) with the percentage of $64.1 \%$ table observed that the highest of tourism people agree (55 replicate with $28.2 \%$ ) of total number 195 person that's mean the level of touring in Shaqlawa district is up to the level of ambition. 


\begin{tabular}{lcc}
\hline X1 & & \\
\hline & Frequency & Percent \\
Disagree & 18 & 9.2 \\
To some extent & 52 & 26.7 \\
Agree & 55 & 28.2 \\
Strongly Agree & 70 & 35.9 \\
\hline Total & 195 & 100 \\
\hline
\end{tabular}

Table showing phrase whether is there an improvement in the services if you visited the city before?

\begin{tabular}{lcc}
\hline X2 & & \\
\hline & Frequency & Percent \\
\hline Disagree & 26 & 13.3 \\
To some extent & 50 & 25.6 \\
\hline Agree & 53 & 27.2 \\
Strongly Agree & 66 & 33.8 \\
\hline Total & 195 & 100 \\
\hline
\end{tabular}

The table prepared by researcher depended on data Questionnaire

From this table it is obvious that highest percentage to the category (agree)with the percentage of $61 \%$. This may consider as a sign for the service improvement in the resort which also encouraged by the residents.

\begin{tabular}{lcc}
\hline X3 & & \\
\hline & Frequency & Percent \\
Disagree & 6 & 3.1 \\
To some extent & 78 & 40 \\
Agree & 27 & 13.8 \\
Strongly Agree & 84 & 43.1 \\
Total & 195 & 100 \\
\hline
\end{tabular}

The table prepared by researcher depended on data Questionnaire

From this table it is obvious that highest percentage to the category (agree)with the percentage of $56.9 \%$. This may related to the good manner and good hospitality between the residents and the foreign tourists.

\begin{tabular}{lcc}
\hline X4 & & \\
\hline & Frequency & Percent \\
\hline Strongly Disagree & 6 & 3.1 \\
\hline Disagree & 20 & 10.3 \\
\hline To some extent & 30 & 15.4 \\
Agree & 90 & 46.2 \\
\hline Strongly Agree & 49 & 25.1 \\
\hline Total & 195 & 100 \\
\hline
\end{tabular}

The table prepared by researcher depended on data Questionnaire form 
Through the above table, it becomes clear to the researcher that the highest percentage was for the category of (agree) and above, and their percentage was $(71.3 \%)$ of the respondents. This indicates that the respondents to the paragraphs of the questionnaire and their percentage mentioned above agree that there is exploitation of expatriates, that is, tourists, by shopkeepers, and this is a not good indication and makes it necessary for the expatriate not to return again and visit a district.

\begin{tabular}{lcc}
\hline X5 & & \\
\hline & Frequency & Percent \\
\hline Strongly Disagree & 20 & 10.3 \\
Disagree & 58 & 29.7 \\
\hline To some extent & 53 & 27.2 \\
Agree & 56 & 28.7 \\
\hline Strongly Agree & 8 & 4.1 \\
\hline Total & 195 & 100 \\
\hline
\end{tabular}

The table prepared by researcher depended on data Questionnaire form

From the above table, it's obvious that the percentage of (neutral) was $67.2 \%$ from the population included in the study. This explain that the transportation costs were relatively high for the tourists. The level of tourism in Shaqlawa district is not competitive level with other provinces of Iraq because most of other provinces like kerbala, Najaf, Hilla, etc they have religion places and graves of Righteous guardians of God like Imam Ali, al Abass, Al-Hamza and in Baghdad Imam ABU HANEFFA and Imam AlKadeem many of visitors come for these places. But still Kurdistan region as general target for people to enjoy them and their opinion for Shaqlawa they express still need more to improving.

\begin{tabular}{lcc}
\hline X6 & & \\
\hline & Frequency & Percent \\
\hline Strongly Disagree & 30 & 15.4 \\
Disagree & 64 & 32.8 \\
\hline To some extent & 58 & 29.7 \\
Agree & 39 & 20 \\
Strongly Agree & 4 & 2.1 \\
Total & 195 & 100 \\
\hline
\end{tabular}

The table prepared by researcher depended on data Questionnaire form

Through the above table, it becomes clear to the researcher that the highest percentage was for the (neutral) category and below, and their percentage was (77.9\%) of the respondents. This indicates that the respondents to the paragraphs of the questionnaire and their percentage mentioned above do not agree to deal with arrivals by the city, which reflects any religious, sectarian or national character. 


\begin{tabular}{lcc}
\hline $\mathbf{X 7}$ & & \\
\hline & & \\
\hline Strongly Disagree & 6 & 3.1 \\
\hline Disagree & 71 & 36.4 \\
\hline To some extent & 90 & 46.2 \\
\hline Agree & 14 & 7.2 \\
Strongly Agree & 14 & 7.2 \\
\hline Total & 195 & 100 \\
\hline
\end{tabular}

The table prepared by researcher depended on data Questionnaire form

Through the above table, it becomes clear to the researcher that the highest percentage was for the (neutral) category and below, and their percentage was (85.7\%) of the respondents. This indicates that the respondents to the paragraphs of the questionnaire and their percentage mentioned above do not agree on whether the level of tourism in Shaqlawa is at a competitive level with other governorates of Iraq.

\begin{tabular}{lcc}
\hline $\mathbf{X 8}$ & & \\
\hline & Frequency & Percent \\
Disagree & 48 & 24.6 \\
To some extent & 95 & 48.7 \\
Agree & 38 & 19.5 \\
Strongly Agree & 14 & 7.2 \\
\hline Total & 195 & 100 \\
\hline
\end{tabular}

The table prepared by researcher depended on data Questionnaire form

Through the above table, it becomes clear to the researcher that the highest percentage was for the (neutral) category and below, and their percentage was (73.3\%) of the respondents. This indicates that the respondents to the paragraphs of the questionnaire and their percentage mentioned above do not agree that the hotel services in Shaqlawa were at the level of ambition.

\begin{tabular}{lcc}
\hline $\mathbf{X 9}$ & & \\
\hline & Frequency & Percent \\
\hline Strongly Disagree & 2 & 1 \\
\hline Disagree & 16 & 8.2 \\
\hline To some extent & 133 & 68.2 \\
\hline Agree & 31 & 15.9 \\
\hline Strongly Agree & 13 & 6.7 \\
\hline Total & 195 & 100 \\
\hline
\end{tabular}

The table prepared by researcher depended on data Questionnaire form

Through the above table, it becomes clear to the researcher that the highest percentage was for the (neutral) category and above, and their percentage was (90.8\%) of the respondents. This indicates that the respondents to the paragraphs of the questionnaire and their percentage mentioned above agree that there should be a role for the media in improving the level of tourism in Shaqlawa. 


\begin{tabular}{lcc}
\hline X10 & & \\
\hline & Frequency & Percent \\
\hline Strongly Disagree & 10 & 5.1 \\
\hline Disagree & 12 & 6.2 \\
\hline To some extent & 113 & 57.9 \\
Agree & 48 & 24.6 \\
Strongly Agree & 12 & 6.2 \\
\hline Total & 195 & 100 \\
\hline
\end{tabular}

The table prepared by researcher depended on data Questionnaire form

Through the above table, it becomes clear to the researcher that the highest percentage was for the (neutral) category and above, and their percentage was (88.7\%) of the respondents. This indicates that the respondents to the paragraphs of the questionnaire and their percentage mentioned above agree on the existence of a role for tourism offices in order to revitalize the tourism sector in Shaqlawa.

\begin{tabular}{lcc}
\hline X11 & & \\
\hline & Frequency & Percent \\
Strongly Disagree & 138 & 70.8 \\
Disagree & 40 & 20.5 \\
To some extent & 5 & 2.6 \\
Strongly Agree & 12 & 6.2 \\
Total & 195 & 100 \\
\hline
\end{tabular}

The table prepared by researcher depended on data Questionnaire form

Through the above table, it becomes clear to the researcher that the highest percentage was for a group of (disagree) and above, and their percentage was (91.3\%) of the respondents. This indicates that the respondents to the paragraphs of the questionnaire and their percentage mentioned above agree that there are no free publications and brochures distributed free of charge as tourist guides to Shaqlawa district.

\begin{tabular}{lcc}
\hline X12 & & \\
\hline & Frequency & Percent \\
\hline Strongly Disagree & 2 & 1 \\
\hline Disagree & 44 & 22.6 \\
To some extent & 115 & 59 \\
Agree & 20 & 10.3 \\
Strongly Agree & 14 & 7.2 \\
Total & 195 & 100 \\
\hline
\end{tabular}

The table prepared by researcher depended on data Questionnaire form

Through the above table, it becomes clear to the researcher that the highest percentage was for the (neutral) category and below, and their percentage was (82.6\%) of the respondents. This indicates that the respondents to the paragraphs of the questionnaire and their percentage mentioned above that there are no tourist guides in the city and this reflects negatively on the tourism sector in the district. 


\begin{tabular}{lcc}
\hline X13 & & \\
\hline & Frequency & Percent \\
\hline Strongly Disagree & 6 & 3.1 \\
\hline Disagree & 50 & 25.6 \\
\hline To some extent & 101 & 51.8 \\
Agree & 26 & 13.3 \\
Strongly Agree & 12 & 6.2 \\
\hline Total & 195 & 100 \\
\hline
\end{tabular}

The table prepared by researcher depended on data Questionnaire form

Through the above table, it becomes clear to the researcher that the highest percentage was for the (neutral) category and above, and their percentage was (80.5\%) of the respondents. This indicates that the respondents to the paragraphs of the questionnaire and their percentage mentioned above find that the services in the tourist areas of the city of Shaqlawa in terms of cleanliness and service are not at the required level.

\begin{tabular}{lcc}
\hline X14 & & \\
\hline & Frequency & Percent \\
\hline Strongly Disagree & 155 & 79.5 \\
\hline Disagree & 22 & 11.3 \\
To some extent & 8 & 4.1 \\
Agree & 2 & 1 \\
Strongly Agree & 8 & 4.1 \\
Total & 195 & 100 \\
\hline
\end{tabular}

The table prepared by researcher depended on data Questionnaire form

Through the above table, it becomes clear to the researcher that the highest percentage was for the category of (disagree) and above, and their percentage (90.8\%) of the respondents. This indicates that the respondents to the paragraphs of the questionnaire and their percentage mentioned above find that the qaimaqamiyya must contribute to the establishment of free entertainment parties for tourists in order to bring the arrivals to the city.

\begin{tabular}{lcc}
\hline X15 & & \\
\hline & Frequency & Percent \\
\hline Strongly Disagree & 4 & 2.1 \\
\hline Disagree & 22 & 11.3 \\
To some extent & 111 & 56.9 \\
Agree & 28 & 14.4 \\
\hline Strongly Agree & 30 & 15.4 \\
\hline Total & 195 & 100 \\
\hline
\end{tabular}

The table prepared by researcher depended on data Questionnaire form

Through the above table, it becomes clear to the researcher that the highest percentage was for the (neutral) category and above, and their percentage was (86.7\%) of the respondents. This indicates that the respondents to the paragraphs of the questionnaire and their percentage mentioned above want to visit the city again. 


\begin{tabular}{|c|c|c|c|c|c|}
\hline \multicolumn{6}{|c|}{ The first axis: services } \\
$\begin{array}{c}\text { Symbol of } \\
\text { phrase }\end{array}$ & chi-square & mean & $\begin{array}{c}\text { Standard } \\
\text { deviation }\end{array}$ & $\begin{array}{c}\text { degree of } \\
\text { freedom }\end{array}$ & $\begin{array}{c}\text { probability } \\
\text { value }\end{array}$ \\
\hline X1 & $29.677 \mathrm{a}$ & 3.91 & 1 & 3 & 0.0000 \\
\hline $\mathrm{X} 2$ & $17.123 \mathrm{a}$ & 3.82 & 1.05 & 3 & 0.0010 \\
\hline $\mathrm{X} 7$ & $152.923 \mathrm{~b}$ & 2.79 & 0.9 & 4 & 0.0000 \\
\hline $\mathrm{X} 8$ & $71.031 \mathrm{a}$ & 3.09 & 0.85 & 3 & 0.0000 \\
\hline $\mathrm{X} 9$ & $294.205 \mathrm{~b}$ & 3.19 & 0.72 & 4 & 0.0000 \\
\hline $\mathrm{X} 10$ & $201.436 \mathrm{~b}$ & 3.21 & 0.85 & 4 & 0.0000 \\
\hline X11 & $231.933 \mathrm{a}$ & 1.5 & 1.02 & 3 & 0.0000 \\
\hline X12 & $209.128 \mathrm{~b}$ & 3 & 0.81 & 4 & 0.0000 \\
\hline $\mathrm{X} 13$ & $152.615 \mathrm{~b}$ & 2.94 & 0.87 & 4 & 0.0000 \\
\hline $\mathrm{X} 14$ & $436.821 \mathrm{~b}$ & 1.39 & 0.94 & 4 & 0.0000 \\
\hline
\end{tabular}

It is evident from the above table that the expressions (X1, X2, X8, X9, X10) have the arithmetic mean greater than the hypothetical mean (3) and this indicates that the respondents' answers to the above statements tend towards approval, meaning they go in the positive direction. As for the remaining expressions, as shown above, in the middle, they are less than the aforementioned hypothetical arithmetic mean. Therefore, we find that the direction of the answers is towards disagreement, any negative except for the statement (X12) The average of her answers was equal to the hypothetical mean, and this indicates that the respondents' answers are neutral, while the standard deviation of all statements is centered around (1), so we conclude that the answers of the sample members for the above statements are homogeneous. We also note that the probability value of all statements was less than the level of statistical significance (0.05), and this indicates that there are statistically significant differences between the answers for each of the levels of measurement and for all statements.

The order of the phrases according to the arithmetic mean: From the above table, we find the following:

1. The statement $(X 1)$ comes in the first place with a mean of (3.91).

2. The statement (X2) comes in second place with a mean of (3.82).

3. The statement $(X 3)$ comes in third place, with a mean of (3.21).

4. The statement (X4) comes in fourth place with a mean of (3.19).

5. The statement (X5) comes in the fifth place with a mean of (3.09).

6. The statement (X6) comes in sixth place with a arithmetic mean (3).

7. The statement (X6) comes in the seventh place, with a mean of (2.94).

8. The statement (X6) comes in the eighth place, with a mean of (2.79).

9. The statement (X6) comes in the ninth place, with a mean of (1.50).

10. The statement (X6) comes in the tenth place with a mean of (1.39).

The second axis: the people of the region dealt with tourists

\begin{tabular}{cccccc}
\hline $\begin{array}{c}\text { Symbol of } \\
\text { phrase }\end{array}$ & chi-square & mean & $\begin{array}{c}\text { Standard } \\
\text { deviation }\end{array}$ & $\begin{array}{c}\text { degree of } \\
\text { freedom }\end{array}$ & $\begin{array}{c}\text { probability } \\
\text { value }\end{array}$ \\
X3 & $90.231 \mathrm{a}$ & 3.97 & 0.98 & 3 & 0.0000 \\
X4 & $108.513 \mathrm{~b}$ & 3.8 & 1.03 & 4 & 0.0000 \\
X5 & $55.590 \mathrm{~b}$ & 2.87 & 1.07 & 4 & 0.0000 \\
X6 & $58.769 \mathrm{~b}$ & 2.61 & 1.04 & 4 & 0.0000 \\
\hline
\end{tabular}


It is evident from the above table that the two expressions $(X 3, X 4)$ their arithmetic mean are greater than the hypothetical mean (3) and this indicates that the respondents' answers to the two statements above are heading towards approval, meaning they go in the positive direction, while the remaining two expressions, as shown above, in their midst are less than the mean of the aforementioned hypothesis. Therefore, we find that the direction of the answers is towards disagreement, i.e. negative, while the standard deviation for all statements is centered on (1). Therefore, we conclude that the answers of the sample members for the above statements are homogeneous. We also note that the probability value of all statements was less than the level of statistical significance (0.05), and this indicates that there are statistically significant differences between the answers for each of the levels of measurement and for all statements.

The order of the phrases according to the arithmetic mean: From the above table we find the following:

1. The term (X3) comes in first place with a mean of (3.97).

2. The statement (X4) comes in second place with a mean of (3.80).

3. The statement (X5) comes in third place, with a mean of (2.87).

4. The statement (X6) comes in fourth place with a mean of (2.61).

\section{Conclusions}

In light of the results obtained from the respondents 'sample answers, we can conclude the following

1. The deterioration of hotel services in Shaqlawa district.

2. The shopkeepers take advantage of the arrivals and sell at double prices, which indicates that there is no control over them

3. Tourism does not rise in Shaqlawa district, according to the tourist sites of neighboring cities such as Turkey and Iran

4. The local government did not think to spend Shaqlawa to develop their city and hold entertainment, folkloric and media parties for the purpose of developing the city.

5. There are positive aspects for the people of Shaqlawa, which is that they do not deal with tourists on a sectarian, sectarian, or racial side.

\section{Recommendations}

By diagnosing glitches, the researcher recommends the following

1. Creation of control committees by the local government to monitor hotel and shop prices on a permanent basis.

Creation of joint committees by the local government and the Health Department to monitor the cleanliness and services of hotels and restaurants in order to monitor the health aspect in them

2. Activating artistic work committees and holding free parties in the tourism season for free to attract the largest number of tourists

3. Print information brochures on the archeology of the region and its tourism sites

4. Establishing free buses for tourists for the purpose of introducing the Shaqlawa district and its outskirts

\section{References}

1. Al-Houri M.T. (2000), Factors and changing demand for tourism on the mountain resorts during the winter season. The study of the theory of a trial, University of Mustansiriya, Baghdad, p. 13.

2. Al-Saadi Nawar (2014), Insights into the Main Difficulties of Achieving. 
3. AL-Taee, Hatem Hatef Abdulkadhim ,Ako Mohammed Tofic,Mariwan Mahdi Jamel.2017. Promoting the Tourism Industry of Kurdistan Region of Iraq (Halabja Province as a Case Study) Journal of Tourism and Hospitality Management June 2017, Vol. 5, No. 1, pp. 103-111.

4. Dabidian, Hooman Dabidian, Mohammed Wafaa Al-Ani, Christopher Hassaan Francke, Ahmed Redwan.2013. Iraq's Tourism Potential. journal of Mena knowledge and learning. No. 87 march 2013.

5. Elmagzoub, M. A., Shaikh, A., Alghamdi, A., \& Rajab, K. (2020). A Review on MIMO Wireless Signals over Fibre for Next Generation Fibre Wireless (FiWi) Broadband Networks. Electronics, 9(12), 2014.

6. Kotler, p. \& BOWEN,j . \& Makens, J. (2003). Marketing for Hospitality and Tourism. Third Ed, Prentice Hall, NewJersey.

7. Laws, Edward A. (2002). Tourism Marketing. continuum, London: newyork.

8. Meier Gerald (1968), The International Economic of Development, New York, Harper and Row Publishers, p. 69. Tourism Authority (2001), The advancement of tourism in Iraq, working paper circle of tourist facilities, from 3 to 5 July.

9. Memon, M. A., Shaikh, A., Taj, K., Memon, M. H., \& Dahri, K. (2017). Route finding for facilitating transportation planning to maintain smooth product flow in supply chain. IBT Journal of Business Studies (JBS), 13(2).

10.Naidoo, Perunjodi;Prabha Ramseook-Munhurrun: Jeynakshi Ladsawut.2010. Tourist satisfaction with mauritius as a holiday destination. Global journal of business research volume 4 number

11. Rayan, zayer,2018. The contribution of tourism marketing to the development of tourism in the Arab world - Algeria Comparative Study Tunisia either UAE-Thesis Université Mohammed KhiderBiskra. République algérienne démocratique et populaire.

12.Sustainable Development of Tourism In Iraq. Analele UniversităNii din Oradea - Seria Geografieno. 1/2014 (June), pp. 32-43. Article no. 241104-646.

13.Places To Visit in Kurdistan Iraq: 2-Week Itinerary. Website https://againstthecompass.com/en/places-visit-iraqi-kurdistan-itinerary/ 